\title{
Do Board Characteristics Affect Financial Reporting Timeliness? An Empirical Analysis
}

\author{
O. Asiriuwa ${ }^{1}$, S. B. Adeyemi ${ }^{2}$, O. R. Uwuigbe ${ }^{1}$, U. Uwuigbe ${ }^{1}$, E. Ozordi ${ }^{1}$, O. Erin ${ }^{1} \&$ O. Omoike ${ }^{1}$ \\ ${ }^{1}$ Department of Accounting, Covenant University, Ogun State, Nigeria \\ ${ }^{2}$ Department of Accounting, University of Lagos, Lagos, Nigeria \\ Correspondence: O. Asiriuwa, Department of Accounting, Covenant University, Ogun State, Nigeria.
}

Received: September 21, 2020

doi:10.5430/ijfr.v12n4p191
Accepted: November 22, 2020

Online Published: May 6, 2021

URL: https://doi.org/10.5430/ijfr.v12n4p191

\begin{abstract}
This research explores the effect of board characteristics on the timeliness of financial reporting from 2012-2018 for 50 listed financial firms. This research, comprising a survey of 50 companies operating in Nigeria's financial sector, gained insights from the agency theory to investigate the impact of board characteristics on the timeliness of financial reporting. Board characteristics were measured using variables such as board size, board independence, board financial expertise, board diligence and CEO gender. We analysed the data using the logistics regression method. Empirically, the results showed that there is a positive association between the financial experience of the board and the timeliness of financial reporting. The size of the board and the independence of the board indicate a negative relationship to the financial reporting timeliness. While, board diligence revealed a negative and insignificant association with the timeliness of financial reporting. Overall, this indicates that Nigerian financial firms' board characteristics have a bigger effect on the timeliness of financial statements. This study contributes to the literature in emerging economies in the field of corporate governance and financial reporting.
\end{abstract}

Keywords: agency theory, board characteristics, board size, financial reporting timeliness, Nigerian financial institutions

\section{Introduction}

The credibility of corporate entities is strengthened by timely reporting and presentation of information because it represents management efficacy and efficiency (Emeh \& Appah, 2013). Any delay in releasing the financial report will give access to some set of investors, primarily those who are wealthy or influential, to acquire costly private unreleased information and lead to information asymmetry. Delay in filing of accounting reports raise the complexity involved with investing decisions (Aktas \& Kargin, 2011). The increased delay decreases the content of the information and the relevance of the financial report (Ettredge, Li, \& Sun, 2006). In ensuring timeliness, attention needs to be given to accuracy because of the trade-off between timeliness and accuracy (Bakare, Taofiq \& Jimoh, 2018). A business could be prompt in publishing its yearly financial accounts, but the required information might not be available in such reports. The accuracy of information also constitutes the quality of the reports. Consequently, if the firms are providing substandard information to meet up with the stipulated deadline, it means that the goal of the Security and Exchange Commission is still not achieved in the preferred manner (Bryant-Kutcher, Peng, \& Weber 2013).

Growing by the complexities of market processes and the growth of the investor sector (both national and international), investors are demanding robust information that is increasingly important. The more quickly businesses file annual reports, the more responsive the consumers and stakeholders are to the details. Stakeholders requires timely financial reports to determine either to commit their capital to a company, or continue to commit it. Delays in reporting financial details contribute to greater inefficiency in the market (Ismail \& Chandler, 2004). In minimizing the asymmetric dissemination of financial information, timely disclosure of information by audited annual reports plays an important role (Jaggi \& Tsui, 1999).

Recently, in an effort to enforce timely reporting of financial information to market participants, the Nigerian Stock Exchange (NSE) placed a fine of 429.5 million on 38 firms who did not submit their annual reports due for the reporting year 2018 (Popoola, 2019). The requirement for high-quality and timely accounting reporting is becoming 
crucial, considering the increasing exposure of Nigerian business entities to global capital markets. Consequently, corporate bodies are expected to follow the disclosure requirements of foreign investors and to supply them with timely reporting in their annual financial reports (Bakare et al., 2018). The increasing knowledge expectations of stakeholders with an institutional interest in financial statements have contributed to accurate and accurate annual reports being sought.

Quite a lot of research have been investigated in developed countries (Singh et al., 2004; Ezat \& El-Masry, 2008; Abdelsalam \& El-Masry, 2008; Mohamad-Nor et al., 2010; Eslami et al., 2015) and emerging economies (Abdullah, 2006; Kamalluarifin, 2016; Bakare et al., 2018) on the subject of board characteristics and timeliness of financial reporting, however, this study has been neglected in Nigeria especially from the firms operating in the financial sector. This provides the motivation to embark on this study. The question is: do board characteristics impact the timeliness of financial reporting in Nigeria?

\section{Hypotheses Development}

The viewpoint of agency theory is based solely on the agent's (director's) deliberate need to protect the principal's (shareholders') interest. The theory takes its stance on the basis that in an ordinary phenomenon a relationship occurs between two parties. It is anticipated that the agent (directors) responsible for carrying out daily activities or services will conduct them on behalf of the principal (owner) and not exclusively but in the pursuit of the desires of the owner (Jensen \& Meckling, 1976). Furthermore, specific costs are associated with agency theory which is the monitoring cost; such cost, are tailored to ensuring that agent unusual activities are curbed. Bonding costs are expenses incurred by the owners to ensure that agents actions (decision making) do not deviate from shareholders expectations and residual loss is attained when both monitoring and bonding cost employed still did not address the selfish and unscrupulous acts of the agent. Hence, agency cost freely emanates transcending to conflict of interest of various stakeholders within the organization.

However, the debate of the distinction of ownership and management is the engine room of this agency problem, thereby providing corporate manager (agent) access to real-time information (insider information) by the virtue that they act on behalf of the principal, outsmart owners of these resources. The only mechanism opened to the shareholders (owners) is to ensure board sub-committees, independent reviewers, experts and experiences mitigate the selfish interest of the agent (Bakare et al., 2018). That's why Kelton and Yang (2008) thought that having independent directors on the company board would help to improve managerial opportunism and control. In doing so, they excel in minimizing the incidence of hiding information. As a result, a board composed by independent directors outside of management influence appears to improve the company's adherence with transparency standards, that can lead to timely financial reporting.

\subsection{Board Size and Timeliness of Financial Reporting}

In the oversight and operational decision making of the management, the directors of the company would perform a vital role. A communication or coordination challenge that represent a huge board less effective to manage than a small board is one of the drawbacks of a big board (Oyeleke et al., 2016). Some research claim that a larger board size encourages further oversight, provides businesses with the variety that assistance them deliver essential resources and reduce ecological risks, alleviates the CEO's dominance and improves the pool of knowledge that derives from the board's diversity (Singh, Mathur, \& Gleason, 2004; Yermack, 1996). Prior empirical review show that a big board is expected to improve related knowledge, may lead to greater influence, provide more vital resources, aid significantly to prevent uncertainty and secure a competitive field for skills and competencies enhancement (Singh et al., 2004). Ezat and El-Masry (2008) concluded that a firm with large board proves to be more informative with respect to websites. Consequently, the composition of the board is considered a deciding issue in the timeliness of the financial statements. Therefore, the size of the board is based on the number of members on the board.

Bakare et al. (2018) analysed the impact of the characteristics of the board on the timeliness of Nigeria's quoted insurance companies ' financial reporting for the years 2011 to 2016. The study adopted a correlation analysis design with a sample size of 15 insurance companies listed. The study was examined using the GLS regression method. The result revealed that board size has a strong and meaningful influence on financial reporting timeliness. Ahmed and Che-Ahmad (2016) examined the effect on Audit Report Lags in Nigeria based on corporate governance characteristics (including the board size). Panel data technique was employed for the data analysis. The size of the board documented a significant correlation with the audit report lag. Based on this literature, this study hypothesised that: 
H1: There is no significant relationship between board size and timeliness of financial reporting

\subsection{Board Independence and Timeliness of Financial Reporting}

The board independence can be a principal factor of the timeliness of financial statements. Kelton and Yang (2008) thought that a large number of independent directors would improve management opportunism and minimize the risk of hiding information from management. Board independence relates to the participation of external directors on issues relating to corporate and strategic direction of a company. A mixed outcome has arisen from the effect of board independence on the timeliness of financial statements. Bakare et al. (2018) analysed the impact of board features on the timeliness of the financial reporting of Kenyan firms. Board independence and board size were used to proxy for board characteristics while the lag in audit report was used to proxy for the dependent variable (timeliness of financial reports). The study analysed 107 listed firms for the period 2012-2014. Multiple regression analysis was adopted, and the result reported that board independence has a significant effect on timeliness of financial statement.

Basuony et al. (2016) investigated board features, ownership characteristics and audit report lag of 11 countries in the Middle East. The independent variables (company characteristics and ownership structure) were proxied by board size and independence, duality of CEO, managerial ownership, own concentration, international ownership and institutional ownership. The study used the period of 2009-2013 with sample size of 201 firms and applied the ordinary least square and ridge regression. They also noticed that the independence of the board is substantially linked to the lag in the audit report. Al-Daoud et al. (2015) also examined the impact of internal corporate governance on the timeliness of Jordanian financial results. The study used a sample size of 112 firms quoted on the Jordanian Stock Exchange for the period 2011 to 2012. The research introduced multivariate regressions, and the result showed that financial report timeliness is strongly linked to independent board. Based on empirical evidence, the hypothesis states that:

$\mathrm{H} 2$ : There is a no significant association between board independence and timeliness of financial reporting

\subsection{Board Financial Expertise and Timeliness of Financial Reporting}

The educational experience of managers can be a key factor in improving the timeliness of financial statements. Education can be defined as a consequence of institutional impact on financial structures and principles (Gray, 1988). A trained director may take a wider viewpoint and greater thought style, and is therefore more likely to consider the broader benefits of different investors (Akhtaruddin \& Rouf, 2011). Administrators with an accounting background could also be more likely to reveal (or disclose) more details to show transparency (Arumona et al., 2019; Uwuigbe et al., 2019). Therefore, as regards the timeliness of financial statements, the presence of directors with accounting and finance education is regarded as a critical factor. Hence, board education will be calculated by the percentage of board directors with background in accounting and finance.

Kamalluarifin (2016) analysed the impact of corporate governance and companies features on the timeliness of corporate Internets by Malaysia's top 95 firms. The survey covered a sample of 100 firms report for the period 2012 in Bursa Malaysia. The study found that the board's experience and the timeliness of corporate internet news show a strong positive relationship. Baatwah, Sallah and Ahmad (2015) report timeliness in Oman in their review of the process of corporate governance and the audit. The study employed variables such as board size, management experience, and audit committee experience. Using the period 2007-2011, the study surveyed a sample size of 116 quoted firms on the Muscat Securities Market (MSM) and employed a panel data approach. The study revealed that board expertise has a significant correlation regarding the timeliness of financial statement.

Clatworthy and Peel (2010) explored corporate governance impact on the timeliness of financial reporting. The research used a sample size of 1,032 from private companies in both the financial and non-financial UK. Hence, the result showed that financial experience increases the timeliness of financial reporting. Similarly, Abdelsalam and Street (2007) assessed the effect of corporate governance on the timeliness of the companies listed in the UK on corporate internet news. The study identified a sample size of 115 firms for the period 2006 that were quoted on the London Stock Exchange. The result revealed that board experience has a positive association regarding the timeliness of corporate internet reporting. Based on literature, the hypothesis states that:

H3: There is no significant association between board financial expertise and timeliness of financial reporting.

\subsection{Board Diligence and Timeliness of Financial Reporting}

The corporate governance code indicated that the board should meet at least once a quarter to perform its oversight role effectively and track the performance of the management. Several studies have shown board diligence is 
improving directors' performance. Cheung, Stouraitis, and Tan (2010) observed that frequent committee meetings benefit from good corporate governance and further claimed that it is correlated with low risk and high market return. Greco (2011) indicated that the efficacy of the board of member is related to the frequency of board meetings, because the frequency of meetings of the board increases the degree of influence over the financial reporting process. Diligent boards raise the level of scrutiny and thereby enhance the consistency of financial reporting (Emeh \& Appah 2013; Erin et al., 2018). Similarly, Hashim and Rahman (2010) reported that the regularity of board meetings would make it easier for auditors to rely on the tight internal controls of a company, which would reduce the workload of the board.

The Eslami et al. (2015) research, on the contrary, evaluated the influence of corporate governance on the timeliness of the listed companies ' financial statements on the Tehran Stock Exchange. As the independent variable, internal corporate governance such as board independence, board size, CEO duality, board experience and board diligence has been used as a proxy. The study adopted a multiple regression analysis and therefore found out that board diligence does not affect the timely report of the statement. Tauringana, Kyeyune and Opio (2016) in their study on timeliness, surveyed 36 companies listed on the Nairobi Stock Exchange for the period 2005 to 2006. . For the analysis, the Ordinary Less Square (OLS) was adopted. The study result showed that the board meeting had a negative connection with the timeliness of the financial results. Based on the empirical review, this the hypothesis states that:

H4: Board diligence is not related to timeliness of financial reporting.

\subsection{CEO Gender and Timeliness of Financial Reporting}

Cheng and Lo (2006) suggested that CEOs have the greater influence over a vast variety of choices, and therefore can also determine whether to share company information and when. Bamber et al. (2010) claimed that the transparency form of financial statements was even more regulated by CEOs. Furthermore, the demise of well-known corporations such as Enron, WorldCom and more recently, Nissan indicates that the CEO has considerable control on the company's reported financial reports. Van der Walt and Ingley (2003) thought that diverse board, also known as the gender of the CEO, could strengthen the behavior of the CEO that enhance the efficiency and reputation of the company.

Expectations about CEO features with timely financial results are focused on the assumption that accounting information has been the result of the collaboration among management and external auditors. Previous studies indicate that a CEO is more concerned with political, organizational, funding decisions and accounting information, such as earnings management and disclosure (Bamber et al., 2010; Bergstresser \& Philippon, 2006; Bertrand \& Schoar, 2003; Uwuigbe et al., 2017). Though it is understood that a CEO has no substantive control over the date of the audit report, it is assumed that the audit work procedure as a whole is controlled by the CEO as a whole.

Khlif and Samaha (2014) stated that it requires an aggregate of 25 days after the financial year-end for accounting information to be submitted for audit and 47 days to register and approve the audited report. The CEO is primarily charged for monitoring the accounting concepts, accounts and forecasts made during the year by the board. If the CEO has ample skills and understanding with these procedures, the audit work continues in a reasonable fashion and work of the auditor is minimized so less mistakes and improvements are made (Jiang, Zhu \& Huang, 2013). The CEO also suggests the extent of technical judgment and thorough checking to be conducted by the auditor (Cohen, Krishnamoorthy, \& Wright, 2002). Gibbins, McCracken, and Salterio (2007) found that the CEO is significantly active in the auditor's agreement on accounting issues at year-end. The timeliness of the audit report may be affected, given the CEO's possible impact on audit risk assessment and negotiation process. Based on this background, the hypothesis states that:

H5: CEO Gender and timeliness of financial reporting

\section{Methodology}

\subsection{Sample Formation}

The sample size for this study is 50 companies for the period of 2012 to 2018 for companies listed in the Nigerian financial sector. The rationale for selecting this period is based on the basis of uniformity in financial information as a result of the adoption in 2012 of International Financial Reporting Standards (IFRS) by all listed firms on the Nigerian Stock Exchange. The choice for 2012 is to ensure conformity and consistency in reporting as a result of the Nigerian Stock Exchange's mandatory adoption of IFRS by listed firms. Because of its attractiveness of the firms listed on the NSE, the financial sector in Nigeria will be of interest to this research. The reason for this sector's choice is based on the fact that on the Nigerian Stock Exchange, the financial segment accounts for 32 per cent of the 
total market capitalization (NSE Factsheet, 2018). As of 31 December 2018, there are currently 57 companies operating in Nigerian Stock Exchange's financial sector.

\subsection{Variable Measurement}

\subsubsection{Dependent Variables}

Timeliness of Financial Reporting: This was proxied using dichotomous procedure of 1 and 0 . A firm will score 1 if they disclose their financial report within the statutory requirement of ninety (90) days required by the Security and Exchange Commission (SEC) for quoted firms and 0 if they disclose outside the period.

\subsubsection{Independent Variables}

This research aims to use several variables as proxies for board characteristics. The variables selected are those based on the previous literature and their related theories are important to the timeliness of financial reporting in Nigerian listed companies. The independence variables used in this study are:

Board Size: The size of the board greatly affects the timeliness of the financial statements. In this analysis, the size of the board is calculated using the total number of board members.

Board independence: this proxy is determined as the number of non-executive in the company's board of directors.

Board Financial Expertise: this is calculated as the proportion of the total board members with accounting and finance qualifications.

Board Diligence: this is measured by the number of meetings held by the board during the financial year.

CEO Gender: this is proxy as a dichotomous variable of 1 and 0 .A firm will score 1 if the CEO if female and 0 if otherwise.

Table 1. Operationalization of variables

\begin{tabular}{|c|c|c|c|c|c|}
\hline $\mathrm{S} / \mathrm{N}$ & Variables & Symbols & Measurement & Used by & A priori Sign \\
\hline & Dependent & & & & \\
\hline \multirow[t]{2}{*}{1} & $\begin{array}{l}\text { Timeliness of } \\
\text { Financial } \\
\text { Reporting }\end{array}$ & TFR & $\begin{array}{l}\text { Measured using the dichotomous } \\
\text { procedure of } 1 \text { and } 0 . \text { A firm will } \\
\text { score } 1 \text { if they disclose their financial } \\
\text { report within the statutory } \\
\text { requirement with the } 90 \text { days and } 0 \text { if } \\
\text { they disclose outside the period. }\end{array}$ & $\begin{array}{l}\text { Schwartz and } \\
\text { Soo (1996). }\end{array}$ & \\
\hline & $\begin{array}{l}\text { Independent } \\
\text { Variable }\end{array}$ & & & & \\
\hline 2 & Board Size & BSIZE & $\begin{array}{l}\text { The size of the board is calculated } \\
\text { using the total number of board } \\
\text { members. }\end{array}$ & $\begin{array}{l}\text { Bakare et al., } \\
(2018)\end{array}$ & + \\
\hline 3 & $\begin{array}{l}\text { Board } \\
\text { Independence }\end{array}$ & BIND & $\begin{array}{l}\text { This is proxy as the number of } \\
\text { non-executive directors in the } \\
\text { company's board of directors. }\end{array}$ & $\begin{array}{l}\text { Abdelsalam } \\
\text { and El-Masry } \\
\text { (2008) }\end{array}$ & - \\
\hline 4 & $\begin{array}{l}\text { Board } \\
\text { Financial } \\
\text { Expertise }\end{array}$ & $\mathrm{BFE}$ & $\begin{array}{l}\text { Measured as the percentage of } \\
\text { members with professional } \\
\text { qualification in accounting and } \\
\text { finance education to the total board. }\end{array}$ & $\begin{array}{l}\text { Kamalluarifin } \\
\text { (2016); Ame } \\
\text { et al. (2016) }\end{array}$ & + \\
\hline 5 & $\begin{array}{l}\text { Board } \\
\text { Diligence }\end{array}$ & $\mathrm{BD}$ & $\begin{array}{l}\text { This is measured by the number of } \\
\text { meetings held by the board during } \\
\text { the financial year. }\end{array}$ & $\begin{array}{l}\text { Ame et al. } \\
(2017)\end{array}$ & + \\
\hline 6 & CEO Gender & CEOGENDER & $\begin{array}{l}\text { Proxy as a dichotomous variable of } 1 \\
\text { and } 0 . \mathrm{A} \text { firm will score } 1 \text { if the CEO } \\
\text { if female and } 0 \text { if otherwise. }\end{array}$ & $\begin{array}{l}\text { Nguyen and } \\
\text { Nguyen } \\
\text { (2017); } \\
\text { Olayinka et al. } \\
\text { (2019) }\end{array}$ & + \\
\hline
\end{tabular}




\subsection{Model Specification and Data Analysis Method}

Timeliness of financial reporting is posited to be a function of board characteristics. This study adapted the model of Eslami et al. (2015).

$$
\begin{gathered}
\text { TFR }=\text { f(BSIZE, BIND, BFE, BD, CEOGENDER }) \\
\text { TFR }_{\text {it }}=\beta_{0 i t}+\beta_{1} \text { BSIZE }_{i t}+\beta_{2} \text { BIND }_{i t}+\beta_{3} \text { BFE }_{i t}+\beta_{4} \text { BD }_{i t}+\beta_{5} \text { CEOGENDER }_{i t}+\mu_{i t}
\end{gathered}
$$

Where,

$$
\begin{gathered}
\mathrm{TFR}_{\mathrm{it}}=\text { Timeliness of Financial Reporting } \\
\mathrm{BSIZE}_{\mathrm{it}}=\text { Board Size } \\
\mathrm{BIND}_{\mathrm{it}}=\text { Board Independence } \\
\mathrm{BFE}_{\mathrm{it}}=\text { Board Financial Expertise } \\
\mathrm{BD}_{\mathrm{it}}=\text { Board diligence } \\
\mathrm{CEOGENDER}_{\mathrm{it}}=\text { CEO Gender } \\
\mathrm{NED}_{\mathrm{it}}=\text { Non-Executive Directors }
\end{gathered}
$$

Specifically, this study used the panel logistic regression technique to clarify the impact of board features on the timeliness of financial reporting. The logistic regression analysis was used in this study because of the dichotomous nature of the dependent variable that take the form of 1 with a probability of success or the value 0 with a probability of failure.

\section{Results}

Table 2. Descriptive statistics

\begin{tabular}{llllllll}
\hline & TFR & BD & BFE & BIND & BSIZE & CEOGENDER & NED \\
\hline Mean & 0.487500 & 5.490625 & 2.337500 & 0.710969 & 10.20937 & 0.118750 & 7.134375 \\
\hline Median & 0.000000 & 5.000000 & 2.000000 & 0.700000 & 10.00000 & 0.000000 & 7.000000 \\
\hline Maximum & 1.000000 & 15.00000 & 8.000000 & 0.920000 & 19.00000 & 1.000000 & 14.00000 \\
\hline Minimum & 0.000000 & 2.000000 & 0.000000 & 0.500000 & 4.000000 & 0.000000 & 2.000000 \\
\hline Std. Dev. & 0.500627 & 1.913466 & 1.764816 & 0.115856 & 3.219733 & 0.324001 & 2.074794 \\
\hline Skewness & 0.050016 & 2.063341 & 0.689858 & 0.029741 & 0.669638 & 2.357075 & 0.225206 \\
\hline Kurtosis & 1.002502 & 9.606401 & 2.723138 & 1.954633 & 2.727373 & 6.555804 & 2.895295 \\
\hline Jarque-Bera & 53.33342 & 808.9873 & 26.40359 & 14.61773 & 24.90651 & 464.8928 & 2.851127 \\
\hline Probability & 0.000000 & 0.000000 & 0.000002 & 0.000670 & 0.000004 & 0.000000 & 0.240373 \\
\hline Sum & 156.0000 & 1757.000 & 748.0000 & 227.5100 & 3267.000 & 38.00000 & 2283.000 \\
\hline Sum Sq. Dev. & 79.95000 & 1167.972 & 993.5500 & 4.281800 & 3306.972 & 33.48750 & 1373.222 \\
\hline Observations & 320 & 320 & 320 & 320 & 320 & 320 & 320 \\
\hline
\end{tabular}

Table 2 revealed the descriptive statistics of board characteristics and timeliness of financial reporting in Nigeria. The dependent variable, which is the timeliness of financial reporting (TFR) has a maximum value of 1 and a minimum value of 0 and a reported mean value of 0487500 . This suggests that about $49 \%$ of sampled companies used in this study complied with the statutory requirement of submitting financial statement within 90 days. This result is actually below average for firms in a highly regulated industry. This low performance could be as a result of the introduction of IFRS in 2011 in Nigeria. Examining the independent variables; the result of board diligence shows that the board meet at least five times in a year. Also, this finding depicts that the board meet at least once in a quarter to discuss company-related matters. This result implies that there is high board activism among the sampled firms. However, this active board does not translate to effective financial reporting process. Similarly, the result of board independence shows that $71 \%$ of sampled firms in the Nigerian financial sector are non-executive directors. 
The role of independent directors cannot be underestimated in the corporate governance mechanism and financial reporting process. They checkmate the excesses of the managers and executive management to align with the corporate goal in order to protect the interest of stakeholders.

Furthermore, the result of board size (BSIZE) ranges from 10 to 11, with a maximum number of directors stand at 19. It is expected that a strong and effective board contribute to high quality of financial reporting process. In the same vein, that diverse and effective board tend to influence management to ensure that financial statements are presented in a timely manner in order to beat regulatory timeframe. Also, the result confirms that at least two members of the board have background in finance-related discipline. It is important to emphasise the professional skill and experience of the board when dealing with the issue of financial reporting and regulatory compliance. The mean value of CEO gender shows that $11 \%$ of the firm's CEO are headed by female director.

Table 3. Pearson correlation matrix of independence variables

\begin{tabular}{llllllll}
\hline Probability & TFR & BD & BFE & BIND & BSIZE & CEOGENDER & NED \\
\hline TFR & 1 & & & & & & \\
\hline BD & 0.086 & 1 & & & & & \\
\hline BFE & -0.034 & 0.211 & 1 & & & & \\
\hline BIND & -0.040 & -0.101 & -0.161 & 1 & & & \\
\hline BSIZE & 0.249 & 0.229 & 0.372 & -0.307 & 1 & & 1 \\
\hline CEOGENDER & 0.086 & -0.161 & -0.125 & 0.041 & -0.171 & 1 & -0.145 \\
\hline NED & 0.178 & 0.154 & 0.261 & 0.233 & 0.841 & & \\
\hline
\end{tabular}

Source: Researcher's Computation (2020) using E-views

Table 3 reveals that a variable's correlation coefficient with respect to itself is 1.000 . This means that a variable has a perfect association with respect to itself. The above table reveals the coefficients for the board characteristics used in the analysis are tested by the variables. The correlation between the timeliness of financial statements (TFR) and board characteristics is of interest in this study. As observed, TFR is positively associated with BD $(r=0.083325)$, CEOGENDER $(\mathrm{r}=0.086485)$, and BSIZE $(\mathrm{r}=0.249591)$. The findings revealed a negative association between TFR and BFE ( $r=-0.034239)$ and BIND $(r=-0.040056)$. The outcome, however, demonstrated a poor association with financial reporting timeliness. For most variables, the inter-correlations between the explanatory variables do not appear to suggest the existence of risks of multicollinearity.

Table 4. Logistics regression analysis

\begin{tabular}{lllll}
\hline Variable & Coefficient & Std.Error & z-Statistic & Prob. \\
\hline $\mathrm{C}$ & 8.153084 & 1.747727 & 4.664964 & 0.0000 \\
\hline BSIZE & -0.813151 & 0.170006 & -4.783072 & 0.0000 \\
\hline NED & 0.999189 & 0.247343 & 4.039688 & 0.0001 \\
\hline BIND & -10.07172 & 2.506898 & -4.017602 & 0.0001 \\
\hline BFE & 0.130357 & 0.048566 & 2.684122 & 0.0073 \\
\hline BD & -0.018724 & 0.044774 & -0.418186 & 0.6758 \\
\hline CEOGENDER & -0.661580 & 0.234169 & -2.825221 & 0.0047 \\
\hline
\end{tabular}

\begin{tabular}{llll}
\hline McFadden R-squared & 0.121820 & Mean dependent var & 0.484375 \\
\hline S.D. dependent var & 0.500539 & S.E. of regression & 0.464932 \\
\hline Akaike info critetion & 1.260308 & Sum squared resid & 67.65874 \\
\hline
\end{tabular}




\begin{tabular}{llll}
\hline Schwarz criterion & 1.342740 & Log likelihood & -194.6494 \\
\hline Hannan-Quinn Criter & 1.293225 & Deviance & 389.2987 \\
\hline Restr. deviance & 443.3016 & Restr.log likelihood & -221.6508 \\
\hline LR. statistic & 54.00294 & Avg.log likelihood & -0.608279 \\
\hline Prob (LR statistic) & 0.000000 & & \\
\hline & & & 320 \\
\hline Obs with Dep=0 & 165 & Total obs & \\
\hline Obs with Dep=1 & 155 & &
\end{tabular}

The findings of binary probit regression analysis are presented in table 4. This analysis reported a McFadden R-squared value of $12.2 \%$, which signifies that $12.2 \%$ systematic variation in TFR is accounted for by the independent variables (BSIZE, BIND, BD, BFE and CEOGENDER). The study revealed that the model statistically significant since the LR statistic and the related prob value of 54.00294 and 0.000000 (p-value<0.05) respectively. This indicates that there exist a significant linear association regarding financial reporting timeliness and the independent variables. As regards to the probability value of the independent variables and their association with the TFR, the findings revealed that board size (BSIZE) has a significant negative relationship with TFR having a Z-value of -4.664 and probability value of 0.0000 is greater than the critical Z-value of 1.96 at $5 \%$ level of significance. This suggests that an increase in BSIZE will cause TFR to decrease by $81 \%$.

However, non-executive director (NED) reveals a significant positive relationship with TFR having a Z-stat of 4.039 at a p-value $(0.0001<0.05$. It therefore indicates that a rise in the number of executive directors would lead to an increase in the timeliness of financial reporting. In the same vein, board independence (BIND) reported a significant negative association with TFR having a Z-value of -4.017 at a p-value $(0.0001<0.05)$. It therefore indicates that an increase in board independence would result in 10.07 decrease in the TFR. CEOGENDER revealed a significant but negative relationship with TFR with a Z-value of -2.825 at a p-value $(0.0047<0.05)$. It indicates that an increase in CEO gender would result in $66 \%$ decrease in the timeliness of financial reporting. This is centered towards the assumption that female directors are more conservative in decision-making. However, board diligence (BD) reported an insignificant relationship with TFR having a $Z$-value of -0.418 with a $p$-value $(0.6758>0.05)$. This suggest that an increase in board meeting will result in $1.8 \%$ decrease in the timeliness of financial reporting but not at a significant level. Board financial expertise (BFE) revealed a significant positive association with timelines of financial reporting with a Z-value of 2.684 and a p-value $(0.0073<0.05)$. This signifies that a rise in the board financial expertise would lead to a $13 \%$ increase in the TFR.

\section{Discussion}

In order to draw a conclusion on the hypotheses testing, there is a need to evaluate the explanatory variables of the model and current a practical assessment. The logistics regression analysis in table 4. Considering the board characteristics variables, the result of the board size (BSIZE) is significant $(0.000<0.05)$ at $5 \%$ significance level. Also, the findings show that board size (BSIZE) reveal a negative significant association with TFR. This is because at a 5 percent significance level, the $\mathrm{z}$-statistics value of -4.664 and prob value of 0.0000 is higher than the crucial $\mathrm{Z}$ value of 1.96. This suggests that an increase in BSIZE will cause TFR to decrease by $81 \%$. This result emphasizes the role of the board in facilitating effective corporate governance mechanism and efficient accounting practices. This underscores the critical role of the board in monitoring and taking strategic decisions. The findings aligned with the studies of Garkaz et al., (2016); Basuony et al., (2016) that confirms that board size plays a key role in facilitating financial reporting timeliness in Middle Eastern countries. Similarly, the empirical evidence on board size in this work corroborates the study of Sakka and Jarboui (2016) which found that size of board significantly reduces the time lag of financial reporting in Tunisia.

Furthermore, the result of board independence (BIND) showed a negative significant association with TFR having a Z-value of -4.017 at a p-value $(0.0001<0.05)$. This indicates that an increase in board independence will result in $10.07 \%$ decrease in timeliness of financial reporting. Quite a number of studies argued that board independence is indispensable in corporate governance quality and financial reporting process (Brown et al., 2009; Habbash, 2010; Mohamad-Nor et al., 2011; Eslami et al., 2016). It is also claimed in studies that a high percentage of independent board directors would improve management incentive tracking and decrease the possibility of management 
concealing information. This will invariably lessen the timeliness of financial reporting. This study's finding is in agreement with the work of Abdelsalam and El-Masry (2008) whose result revealed that independence of the board affect the timely reporting of the financial statement. The study of Ilaboya and Christian (2014) found that credible members of the board should be persons of honesty that can foster timely reporting of financial statement. Independent directors are selected to protect the welfares of the stockholders be it majority or minority shareholder.

Another important board characteristic variable is board financial expertise (BFE); the finding shows that board financial expertise maintained a positive significant association with TFR with a Z-value of 2.684 and a p-value $(0.0073<0.05)$. This signifies that an increase in the board financial expertise would lead to $13 \%$ increase in TFR. It is important to emphasise the professional skill and experience of the board when evaluating the characteristics of the board. Studies on board financial expertise have shown that directors with accounting and/or finance background contribute immensely financial management of any organisation stakeholders (Haniffa \& Cooke, 2002; Akhtaruddin \& Rouf, 2011; Emeh \& Appah, 2013). Also, it is argued that board with financial expertise strengthen board quality which invariably has positive impact on financial reporting timeliness. This suggests that the financial education of the board matters when disclosing relevant information regarding financial reports. With regards to the impact of board education, our findings extend the studies of Cheung, Stouraitis, \& Tan, 2010; Eslami et al., 2015; Ahmed \& Che-Ahmad, 2016.

Another important feature of the board is the CEO gender; studies on gender diversity has gained prominence in management literature in recent times. Most studies argued that female executive are more accountable than male executive. Analysis from this study observed that CEOGENDER produced a significant with negative relationship with TFR with a Z-value of -2.825 at a p-value $(0.0047<0.05)$. This signifies that a rise in CEO gender would lead in $66 \%$ decrease in timeliness of financial reporting. Large number of studies opine that higher participation of women on corporate board promote honesty and high ethical values (Bertrand \& Schoar, 2003; Francis, Huang, Rajgopal \& Zang, 2008; Bamber, Jiang \& Wang 2010). While others believe that inclusion of female directors on the board add credibility and increased level of transparency regarding financial reporting process (Bertrand \& Schoar, 2003; Bergstresser \& Philippon, 2006; Khlif \& Samaha, 2014). The study revealed that the presence of female director on the board have significant effect on the timeliness of financial statement. The result is in tandem with prior studies like McCracken and Salterio, (2007); Baatwah, et al., (2015); Khuong and Vy, (2017). These studies found that female CEO exhibit high level of professional scepticism and positive attitude in influencing financial reporting process.

Board diligence is one of the key features of the board, the empirical findings from this study shows that board diligence (BD) reported an insignificant relationship with TFR having a Z-value of -0.418 with a p-value $(0.6758>0.05)$. This suggests that an increase in board meeting will result in $1.8 \%$ decrease in timeliness of financial reporting but not at a significant level. The Corporate Governance Code proposed that the companies board should meet at least once a quarter to adequately fulfill its oversight role and track management's performance. It is argued that effective and diligent board strengthen oversight functions which results to enhanced financial reporting process (Hashim \& Rahman, 2010). The result of this study shows that board meet at least six times in a financial year. This contributed to the timeliness of financial reporting of selected financial companies in Nigeria, though, not significant. There have been mixed results in literature concerning the effect of board diligence on the timeliness of financial reporting. The studies of Emeh and Appah, 2013; Li, et al., 2014; Tauringana, et al., 2016 revealed no significant association between board diligence and timeliness of financial reporting. While the work of Ahmed and Che-Ahmad, 2016; Al-Daoud et al., 2015 reported a significant relationship between board diligence and timeliness of financial reporting. This inconclusive evidence calls for further investigation on the impact of board diligence on timeliness of financial reporting.

\section{Conclusion}

This research examined the effect of board characteristics on timeliness of financial reporting in Nigeria. In achieving the aims of this study, information were obtained from the annual reports, Nigerian Stock Exchange Factbook and corporate websites of fifty (50) quoted companies in the Nigerian financial sector from 2012 - 2018. There are five hypotheses formulated and tested using binary logistic analysis for all hypothesis 1 to 5 respectively. A significant linear association exist regarding board characteristics and timeliness of financial reporting in Nigeria. However, in terms of specific variables, the study's finding documents that a significant positive association exist regarding board financial expertise and timeliness of financial reporting. Board size and board independence revealed a negative and significant relationship with timelines of financial reporting. While, board diligence revealed 
an insignificant negative association with timeliness of financial reporting. It can therefore be concluded that board characteristics in the financial sector affect the timeliness of financial statement.

The research marks a substantive methodological advancement in the measurement of timeliness of financial statement by adopting the regulatory requirement instead of the financial reporting lag and audit reporting lag. Beyond the common cross-sectional and pooled data studies, this study will provide empirical evidence using the binary logistic regression technique, which has not been used in other studies in Nigeria. Further research could examine other variables such penalties, merger and acquisition on timeliness of financial reporting either at a country level or cross-country setting. This will help to better understanding the reporting regulations of different countries and the level of implementation.

\section{Acknowledgement}

The authors appreciate the assistance and sponsorship of Covenant University, Ota in making this research work a success.

\section{References}

Abdelsalam, O., \& El-Masry, A. (2008). The impact of board independence and ownership structure on the timeliness of corporate internet reporting of Irish-listed companies. Managerial Finance, 34(12), 907-918. https://doi.org/10.1108/03074350810915842

Ahmed, M. I., \& Che-Ahmad, A. (2016). Effects of corporate governance characteristics on audit report lags. International Journal of Economics and Financial Issues, 6(7S), 159-164.

Akhtaruddin, M., \& Rouf, M. A. (2012). Corporate governance, cultural factors and voluntary disclosure: Evidence from selected companies in Bangladesh. Corporate Board: Role, Duties and Composition, 8(1), 48-61. https://doi.org/10.22495/cbv8ilart4

Aktas, R., \& Kargin, M. (2011). Timeliness of reporting and the quality of financial information. International Research Journal of Finance and Economics, 63(1), 71-77.

Al-Daoud, K. A., Ismail, K. N. I. K., \& Lode, N. A. (2014). The timeliness of financial reporting among Jordanian companies: Do companies and board characteristics, and audit opinion matter?. Asian Social Science, 10(13), 191-201. https://doi.org/10.5539/ass.v10n13p191

Ame, J., Arumona, J., \& Erin, O. (2017). The impact of ownership structure on firm performance: Evidence from listed manufacturing companies in Nigeria. International Journal of Accounting, Finance and Information System, 1(1), 293-305.

Arumona, J., Erin, O., Onmonya, L., \& Omotayo, V. (2019). Board financial education and firm performance: Evidence from the healthcare sector in Nigeria. Academy of Strategic Management Journal, 18(4), 1-18.

Baatwah, S. R., Salleh, Z., \& Ahmad, N. (2015). Corporate governance mechanisms and audit report timeliness: Empirical evidence from Oman. International Journal of Accounting, Auditing and Performance Evaluation, 11(3-4), 312-337. https://doi.org/10.1504/IJAAPE.2015.071580

Bakare, O. U., Taofiq, A., \& Jimoh, J. A. (2018). Effect of board characteristics on timeliness of financial reporting of listed insurance firms in Nigeria. Online Journal of Arts, Management \& Social Sciences, 3(1), 126-136.

Bamber, L. S., Jiang, J., \& Wang, I. Y. (2010). What's my style? The influence of top managers on voluntary corporate financial disclosure. The Accounting Review, 85(4), 1131-1162. https://doi.org/10.2308/accr.2010.85.4.1131

Basuony, M. A. K., Ehab, K. A. M., Mostaq, M. H., \& Omar, K. M. (2016). Board characteristics, ownership structure and audit report lag in the Middle East. International Journal of Corporate Governance, 7(2), 180-205. https://doi.org/10.1504/IJCG.2016.078388

Bergstresser, D., \& Philippon, T. (2006). CEO incentives and earnings management. Journal of Financial Economics, 80(3), 511-529. https://doi.org/10.1016/j.jfineco.2004.10.011

Bertrand, M., \& Schoar, A. (2003). Managing with style: The effect of managers on firm policies. The Quarterly Journal of Economics, 118(4), 1169-1208. https://doi.org/10.1162/003355303322552775

Brown, P., Dobbie, G. W., \& Jackson, A. B. (2009). Measures of the timeliness of earnings: An empirical investigation. January; Australian Research Council's Discovery Projects, 1-36.

Bryant-Kutcher, L., Peng, E. Y., \& Weber, D. P. (2013). Regulating the timing of disclosure: Insights from the 
acceleration of 10-K filing deadlines. Journal of Accounting and Public Policy, 32(6), 475-494. https://doi.org/10.1016/j.jaccpubpol.2013.08.003

Cheng, Q., \& Lo, K. (2006). Insider trading and voluntary disclosures. Journal of Accounting Research, 44(5), 815-848. https://doi.org/10.1111/j.1475-679X.2006.00222.x

Cheung, Y. L., Stouraitis, A., \& Tan, W. (2010). Does the quality of corporate governance affect firm valuation and risk? Evidence from a corporate governance scorecard in Hong Kong. International Review of Finance, 10(4), 403-432. https://doi.org/10.1111/j.1468-2443.2010.01106.x

Clatworthy, M. A., \& Peel, M. J. (2010, December). Does corporate governance influence the timeliness of financial reporting? Evidence from UK private companies. In HEC Accounting and Management Control Department Research Seminar (Vol. 10, pp. 1-28).

Cohen, J., Krishnamoorthy, G., \& Wright, A. M. (2002). Corporate governance and the audit process. Contemporary Accounting Research, 19(4), 573-594. https://doi.org/10.1506/983M-EPXG-4Y0R-J9YK

Emeh, Y., \& Appah, E. (2013). Audit committee and timeliness of financial reports: Empirical evidence from Nigeria. Journal of Economics and Sustainable Development, 4(20), 14-25.

Erin, O., Asiriuwa, O., Olojede, P., Ajetunmobi, O., \& Usman, T. (2018). Does risk governance impact bank performance? Evidence from the Nigerian Banking Sector. Academy Accounting and Finance Journal, 4(1), $1-14$.

Eslami, R., Armin, A., \& Jaz, H. R. (2016). A study on the effect of corporate governance on the timeliness of financial reports of listed firms on Tehran stock exchange. Academic Journal of Accounting and Economic Researches, 4(4), 140-152.

Ettredge, M. L., Li, C., \& Sun, L. (2006). The impact of SOX Section 404 internal control quality assessment on audit delay in the SOX era. Auditing: A Journal of Practice \& Theory, 25(2), 1-23. https://doi.org/10.2308/aud.2006.25.2.1

Ezat, A., \& El-Masry, A. (2008). The impact of corporate governance on the timeliness of corporate internet reporting by Egyptian listed companies. Managerial Finance, 34(12), 848-867. https://doi.org/10.1108/03074350810915815

Francis, J., Huang, A. H., Rajgopal, S., \& Zang, A. Y. (2008). CEO reputation and earnings quality. Contemporary Accounting Research, 25(1), 109-147. https://doi.org/10.1506/car.25.1.4

Gibbins, M., McCracken, S. A., \& Salterio, S. E. (2007). The chief financial officer's perspective on auditor-client negotiations. Contemporary Accounting Research, 24(2), 387-422. https://doi.org/10.1506/9208-G324-1R15-4U3H

Gray, S. J. (1988). Towards a theory of cultural influence on the development of accounting systems internationally. Abacus, 24(1), 1-15. https://doi.org/10.1111/j.1467-6281.1988.tb00200.x

Greco, G. (2011). Determinants of board and audit committee meeting frequency: Evidence from Italian companies. Managerial Auditing Journal, 26(3), 208-229. https://doi.org/10.1108/02686901111113172

Habbash, M. (2010). The effectiveness of corporate governance and external audit on constraining earnings management practices in the UK. Ph.D. thesis, Durham University. Retrieved from http://ethesis.dur.ac.uk/448

Hashim, U. J., \& Abdul Rahman, R. (2011, November). Board independence, board diligence, board expertise and impact on audit report lag in Malaysian market. Finance and Corporate Governance Conference. https://doi.org/10.2139/ssrn.1717479

Ilaboya, O. J., \& Christian, I. (2014). Corporate governance and audit report lag in Nigeria. International Journal of Humanities and Social Science, 4(13), 172-180.

Ismail, K. N., \& Chandler, R. (2004). The timeliness of quarterly financial reports of companies in Malaysia. Asian Review of Accounting, 12(1), 1-18. https://doi.org/10.1108/eb060770

Jaggi, B., \& Tsui, J. (1999). Determinants of audit report lag: Further evidence from Hong Kong. Accounting and Business Research, 30(1), 17-28. https://doi.org/10.1080/00014788.1999.9728921

Jensen, M., \& Meckling, W. (1976). Theory of the firm: Managerial behavior, agency costs and ownership structure. Journal of Financial Economics, 3, 305-360. https://doi.org/10.1016/0304-405X(76)90026-X 
Jiang, F., Zhu, B., \& Huang, J. (2013). CEO's financial experience and earnings management. Journal of Multinational Financial Management, 23(3), 134-145. https://doi.org/10.1016/j.mulfin.2013.03.005

Kamalluarifin, W. F. (2016). The influence of corporate governance and firm characteristics on the timeliness of corporate internet reporting by top 95 companies in Malaysia. Procedia Economics and Finance, 35, 156-165. https://doi.org/10.1016/S2212-5671(16)00020-4

Kelton, A. S., \& Yang, Y. W. (2008). The impact of corporate governance on Internet financial reporting. Journal of Accounting and Public Policy, 27(1), 62-87. https://doi.org/10.1016/j.jaccpubpol.2007.11.001

Khlif, H., \& Samaha, K. (2014). Internal control quality, Egyptian standards on auditing and external audit delays: Evidence from the Egyptian stock exchange. International Journal of Auditing, 18(2), 139-154. https://doi.org/10.1111/ijau.12018

Khuong, N. V., \& Vy, N. T. X. (2017). CEO characteristics and timeliness of financial reporting of Vietnamese listed companies. VNU Journal of Science: Economics and Business, 33(5), 100-107. https://doi.org/10.25073/2588-1108/vnueab.4127

Li, Y., Zhang, D., \& Wang, X. (2014). The influence of corporation governance structure on internal control audit report lag: evidence from China. Accounting \& Taxation, 6(2), 101.

Mohamad-Nor, M. N., Shafie, R., \& Wan-Hussin, W. N. (2010). Corporate governance and audit report lag in Malaysia. Asian Academy of Management Journal of Accounting and Finance, 6(2), 51-84.

Olayinka, E., Uwuigbe, U., Eriabie, S., Uwuigbe, O., \& Omoike, O. (2019). Does enterprise risk management impact accounting quality? Evidence from the Nigerian financial institutions. Investment Management and Financial Innovations, 16(4), 1-15. https://doi.org/10.21511/imfi.16(4).2019.02

Oyeleke, O., Erin, O., \& Emeni, F. (2016). Female directors and tax aggressiveness of listed banks in Nigeria (3rd ed.). International Conference on African Development Issues (CU-ICADI 2016).

Popoola, F. (2019, February). Financial statements: NSE slams N 429.5m fines. Punch Newspaper. Retrieved from https://punchng.com/financial-statements-nse-slams-n429-5m-fines-on-38-firms

Singh, M., Mathur, I., \& Gleason, K. C. (2004). Governance and performance implications of diversification strategies: Evidence from large US firms. Financial Review, 39(4), 489-526. https://doi.org/10.1111/j.0732-8516.2004.00086.x

Tauringana, V., Kyeyune, M. F., \& Opio, P. J. (2008). Corporate governance, dual language reporting and the timeliness of annual reports on the Nairobi stock exchange. In Corporate Governance in less developed and emerging economies (pp. 13-37). Emerald Group Publishing Limited. https://doi.org/10.1016/S1479-3563(08)08001-8

Uwuigbe, O., Olorunshe, O., Uwuigbe, U., Ozordi, E., Asiriuwa, O., Asaolu, T., ... Erin, O. (2019). Corporate governance and financial statement fraud among listed firms in Nigeria. IOP Conference Series: Earth and Environmental Science. https://doi.org/10.1088/1755-1315/331/1/012055

Uwuigbe, U., Erin, O., Uwuigbe, O., Igbinoba, E., \& Jafaru, J. (2017). Ownership structure and financial disclosure quality: Evidence from listed firms in Nigeria. Journal of Internet Banking and Commerce, 22(8), 1-12.

Van der Walt, N., \& Ingley, C. (2003). Board dynamics and the influence of professional background, gender and ethnic diversity of directors. Corporate Governance: An International Review, 11(3), 218-234. https://doi.org/10.1111/1467-8683.00320

Yermack, D. (1996). Higher market valuation of companies with a small board of directors. Journal of Financial Economics, 40(2), 185-211. https://doi.org/10.1016/0304-405X(95)00844-5

\section{Copyrights}

Copyright for this article is retained by the author(s), with first publication rights granted to the journal.

This is an open-access article distributed under the terms and conditions of the Creative Commons Attribution license (http://creativecommons.org/licenses/by/4.0/). 